\title{
A survey of ectoparasite infestation in dogs in Tehran, Iran
}

\author{
Um levantamento da infestação de ectoparasitos em cães em Teerã, Irã

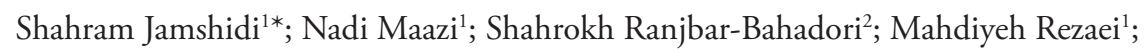 \\ Pedram Morakabsaz ${ }^{3}$; Morteza Hosseininejad ${ }^{4}$
}

${ }^{1}$ Department of Clinical Sciences, School of Veterinary Medicine, University of Tehran, Tehran, Iran

${ }^{2}$ Department of Parasitology, School of Veterinary Medicine, Islamic Azad University, Garmsar branch, Garmsar, Iran

${ }^{3}$ School of Veterinary Medicine, Islamic Azad University, Garmsar Branch, Garmsar, Iran

${ }^{4}$ Department of Clinical Sciences, School of Veterinary Medicine, University of Shahrekord, Shahrekord, Iran

Received November 7, 2011

Accepted March 14, 2012

\begin{abstract}
This survey was conducted to identify and estimate the frequencies of ectoparasites of dogs in Tehran, Iran. A total of $143 \mathrm{dogs}$ attended at the Small Animal Hospital of the Veterinary School, the University of Tehran, were examined for the presence of ectoparasites and dermatological lesions. Ectoparasite specimens and blood samples were sent to parasitology and hematology laboratories, respectively. Ticks were the most frequent ectoparasite $(36.4 \%, 52 / 143)$, followed by fleas $(29.4 \%, 42 / 143)$, mites $(25.9 \%, 37 / 143)$, and lice $(8.4 \%, 12 / 143)$. Mixed infestations with two or more ectoparasites were detected in eight dogs. Rhipicephalus bursa was the most frequent ectoparasite in spring and summer. Ectoparasitic infestations were recorded mainly in large breeds and juvenile animals. Eosinophilia was more observed in dogs infested with Sarcoptes scabiei. The most common clinical sign, skin pruritus, was associated with mite and lice infestations. These results indicate that the tick R. bursa was the most prominent species of ectoparasite found in the evaluated group, followed by Ctenocephalides canis and S. scabiei var canis.
\end{abstract}

Keywords: Ectoparasites, Rhipicephalus bursa, dogs, Ctenocephalides canis, Sarcoptes scabiei, Iran.

\section{Resumo}

Esta pesquisa foi realizada para identificar e estimar a frequência de ectoparasitas de cães em Teerã, Irã. Um total de 143 cães, atendidos no Hospital de Pequenos Animais da Faculdade de Veterinária da Universidade de Teerã, foi examinado para a pesquisa de ectoparasitas e lesôes cutâneas. Espécimes de ectoparasitos e amostras de sangue coletadas foram enviadas para exame em laboratório de parasitologia e hematologia, respectivamente. Os carrapatos foram os ectoparasitos mais frequentemente encontrados $(36,4 \%, 52 / 143)$, seguidos por pulgas $(29,4 \%, 42 / 143)$, sarnas $(25,9 \%, 37 / 143)$ e piolhos $(8,4 \%, 12 / 143)$. Infestaçóes mistas com dois ou mais ectoparasitos foram observadas em oito cães. Rhipicephalus bursa foi o ectoparasito mais frequente na primavera e verão. Infestaçóes de ectoparasitos foram registradas principalmente em raças maiores e animais jovens. Eosinofilia foi mais observado em cães infestados com Sarcoptes scabiei. O sinal clínico mais comum, prurido na pele, esteve associado às infestaçóes por ácaros e piolhos. Estes resultados indicam o carrapato $R$. bursa como ectoparasito mais comum no grupo avaliado, seguido por Ctenocephalides canis e S. scabiei var canis.

Palavras-chave: Ectoparasitos, Rhipicephalus bursa, cães, Ctenocephalides canis, Sarcoptes scabiei, Irã.

\section{Introduction}

Ectoparasites live on, feed on and inhabit the external body surfaces of vertebrates, including dogs (WALL; SHEARER, 2001). They have considerable pathogenicity and may even cause death, according to parasitism intensity, nutritional status and the host's immunological condition (SCOTT et al., 2001). They can also act as vectors for a wide variety of infectious agents such

\footnotetext{
*Corresponding author: Shahram Jamshidi

School of Veterinary Medicine, University of Tehran, Qareeb Street, Azadi Av, P.O. Box: 14155-6453, Tehran, Iran

e-mail:shjamshidi@ut.ac.ir
}

as: Babesia spp., Ehrlichia spp., Anaplasma spp., Rickettsia spp., Borrelia spp. and Yersinia pestis, and/or as intermediate hosts of filarids and cestodes, which cause serious diseases in dogs and people in contact with them (LITTLE, 2009). In addition, canine sarcoptic mange and fleas can directly cause pruritic skin lesions in humans (HEWITT et al., 1971). It has been reported that various zoonotic vector-borne diseases are endemic in different parts of Iran, such as plague, murine typhus, endemic typhus fever, cutaneous and visceral leishmaniasis, tick-borne relapsing fever and Lyme disease (FAULDE, 2010). 
Identifying ectoparasites and understanding their distribution are fundamental for designing control programs and strategies. Despite the significant dog population in Tehran, information regarding ectoparasites on domestic dogs is still lacking (SHOORIJEH et al., 2008; BAHRAMI; DELPISHEH, 2010; TAVASSOLI et al., 2010). This study was carried out to identify and estimate the frequencies of ectoparasites occurring on dogs in Tehran.

\section{Materials and Methods}

Tehran lies at $35^{\circ} 68^{\prime} \mathrm{N}$ and $51^{\circ} 35^{\prime} \mathrm{E}$ and is at an altitude of 1191 meters above sea level. Its climate is largely defined by its geographical location, with the Alborz Mountains towering to its north and the central desert to the south. The city has a semi-arid, continental climate.

One hundred and forty-three dogs referred to the Small Animal Hospital of the Veterinary School, the University of Tehran, a reference center in Iran, were examined for the presence of ectoparasites in different seasons of the year (from September 2006 to September 2007). Information about age, sex, body weight, living environment, clinical signs and season were recorded. All the dogs were classified in one of two groups, juvenile ( $\leq 6$ months) or adult (>6 months), and in one of two categories, small breeds ( $\leq 10 \mathrm{~kg}$ ) or large breeds $(>10 \mathrm{~kg})$. They also were divided into outdoor and indoor, based on their access to the outdoor environment.

Ticks, fleas and lice were collected respectively by using forceps, combing or brushing. From dogs with dermatological lesions, four samples of deep skin scrapings were collected from the head, pinnae, thoracic-abdominal areas, and elbows or paws. The ectoparasite species were identified in accordance with the keys provided by Wall and Shearer (2001). After blood sample collection (in EDTA-coated tubes) from all the dogs by means of cephalic venipuncture, a complete blood cell count (CBC) was performed. A chi-square test was used to determine any significant associations between age, sex, body weight, season, hair shedding, pruritus and ectoparasite species $(\mathrm{p} \leq 0.05)$. Furthermore, the Kolmogorov-Smirnov and independent $t$ tests were applied to analyze the hematological parameters.

\section{Results}

Among the 143 dogs examined, 52 (36.4\%) were found to be infested with ticks (Rhipicephalus bursa and Rhipicephalus sanguineus), while fleas (Ctenocephalides canis and Pulex irritans), mites (Sarcoptes scabiei var. canis, Otodectes cynotis and Demodex canis) and lice (Trichodectes canis and Linognathus setosus) were found on $42(29.4 \%), 37$ (25.9\%), and 12 (8.4\%) of the dogs, respectively. The most common ectoparasite species was the tick $R$. bursa, whereas $D$. canis was the parasite least frequently detected. Mixed infestations with two or more ectoparasites were detected on eight dogs (5.6\%). In the spring and summer, ticks (45.6\% and 51.7\%), especially $R$. bursa (38.6\% and $44.8 \%$ ), were the most prevalent ectoparasitic species. During the fall, fleas were the most frequent parasites $(55.6 \%)$, whereas mites $(38.1 \%)$, especially S. scabiei var. canis $(33.3 \%)$, prevailed in winter (Table 1). Ectoparasitic infestations were recorded on 82 male dogs (57.3\%) and 61 female dogs (42.7\%). Rhipicephalus bursa was the most abundant infesting species both on males (32.5\%) and on females (24.6\%). The least abundant ectoparasitic species found in this study were L. setosus on males $(1.2 \%)$ and $D$. canis on females $(1.6 \%)$.

Mites and ticks were the most frequently collected ectoparasites in 90 infested juvenile dogs (31.1\%) and 53 infested adult dogs $(47.2 \%)$, respectively. Flea and tick infestations were more common among outdoor animals (40.5\%) than among indoor dogs (25.2\%). Mite infestation was more frequent among indoor dogs. Large dog breeds were more frequently affected by all ectoparasites (ticks, fleas, mites and lice) than small breeds (67.1\%, 96/143).

The most common clinical sign among the animals examined was pruritus $(55.9 \%)$, followed by alopecia (30.8\%). Pruritus was observed more among animals infested by mites $(43.8 \%)$ and fleas (26.3\%). Thirty infested dogs (20.9\%) had eosinophilia and almost half of these were mite-infested. Low hematocrit levels were detected in forty infested dogs (27.9\%).

\section{Discussion}

In the present study, nine distinct species of ectoparasites were collected from dogs in Tehran, Iran (Table 1). The most common ones were ticks $(R$. bursa), fleas $(C$. canis) and mites (S. scabiei var. canis). These results are in agreement with those of González et al. (2004) in Argentina, Nithikathkul et al. (2005) in Thailand, Aldemir (2007) in Turkey and Ghosh et al. (2007) in Bangladesh, India and Pakistan.

Ctenocephalides canis was reported as the most prevalent flea species on dogs in countries such as Ireland (WALL et al., 1997), New Zealand (GUZMAN, 1984), Thailand (NUCHJANGREED;

Table 1. Ectoparasite species and frequency of infestations detected in dogs in Tehran according to season.

\begin{tabular}{|c|c|c|c|c|c|c|c|c|c|c|c|c|c|c|c|c|c|c|c|c|}
\hline \multirow{4}{*}{ Seasons } & \multicolumn{18}{|c|}{ Ectoparasite species } & \multirow{3}{*}{\multicolumn{2}{|c|}{ Total }} \\
\hline & \multicolumn{4}{|c|}{ Ticks } & \multicolumn{4}{|c|}{ Fleas } & \multicolumn{4}{|c|}{ Lice } & \multicolumn{6}{|c|}{ Mites } & & \\
\hline & \multicolumn{2}{|c|}{ R. bursa } & \multicolumn{2}{|c|}{ R. sanguineus } & \multicolumn{2}{|c|}{ C. canis } & \multicolumn{2}{|c|}{ P. irritans } & \multicolumn{2}{|c|}{ T. canis } & \multicolumn{2}{|c|}{ L. setosus } & \multicolumn{2}{|c|}{ S. scabiei } & \multicolumn{2}{|c|}{ O. cynotis } & \multicolumn{2}{|c|}{ D. canis } & & \\
\hline & $\#$ & $\%$ & $\#$ & $\%$ & $\#$ & $\%$ & $\#$ & $\%$ & $\#$ & $\%$ & $\#$ & $\%$ & $\#$ & $\%$ & $\#$ & $\%$ & $\#$ & $\%$ & $\#$ & $\%$ \\
\hline Spring & 22 & 38.6 & 4 & 7.0 & 8 & 14.0 & 2 & 3.5 & 4 & 7.0 & 1 & 1.8 & 14 & 24.6 & 2 & 3.5 & 0 & 0 & 57 & 39.9 \\
\hline Summer & 13 & 44.8 & 2 & 6.9 & 4 & 13.8 & 2 & 6.9 & 3 & 10.3 & 1 & 3.4 & 3 & 10.3 & 1 & 3.4 & 0 & 0 & 29 & 20.3 \\
\hline Fall & 5 & 13.9 & 1 & 2.8 & 19 & 52.8 & 1 & 2.8 & 1 & 2.8 & 0 & 0 & 6 & 16.7 & 0 & 0 & 3 & 8.3 & 36 & 25.2 \\
\hline Winter & 3 & 14.3 & 2 & 9.5 & 5 & 23.8 & 1 & 4.8 & 0 & 0 & 2 & 9.5 & 7 & 33.3 & 1 & 4.8 & 0 & 0 & 21 & 14.6 \\
\hline Total & 43 & 30.1 & 9 & 6.3 & 36 & 25.2 & 6 & 4.2 & 8 & 5.6 & 4 & 2.8 & 30 & 21.0 & 4 & 2.8 & 0 & 2.1 & 143 & 100 \\
\hline
\end{tabular}

Note: Symbols: (\#) number of ectoparasites collected; (\%) percentage. 
SOMPRASONG, 2007), some area of England (EDWARDS, 1969) and Nigeria (AGBOLADE et al., 2008). Although C. felis was not found in this study, it was reported to be the most abundant flea in dogs of the Caspian Sea area of Iran (TAVASSOLI et al., 2010), Spain (GRACIA et al., 2008) and United State of America (HARMAN et al., 1987; DURDEN et al., 2005). These differences might be due to the dissimilar temperature and humidity in each geographical area, which affects the survival and reproduction of fleas.

Although previous studies reported that $R$. sanguineus was the most frequent tick species in dogs in two different areas of Iran, Ilam (BAHRAMI; DELPISHEH, 2010) and Shiraz (SHOORIJEH et al., 2008), the present study in Tehran found that the tick $R$. bursa was more frequent. This discrepancy is not easy to explain, but environmental and climatic factors as well as social and cultural factors relating to urban or rural ways of life might play a role. More studies are needed in order to understand the biology of these flea and tick species, as well as their geographical distribution trends.

Although ectoparasites were found on dogs throughout the year in Tehran, they were more prevalent in spring (Table 1), and there was a significant relationship between season and infestation $(\mathrm{p}=0.03)$. In detail, ticks were collected more frequently in spring and summer, fleas in autumn and mites in winter. These findings are similar to what was observed by other investigators in other countries (GONZÁLEZ et al., 2004; BECK et al., 2006; RINALDI et al., 2007; GRACIA et al., 2008; XHAXHIU et al., 2009). Ectoparasites require optimum temperature and humidity for growth, development, reproduction and survival, as well as access to food (WALL; SHEARER, 2001). The seasonal occurrence of ectoparasitic infestations may be associated with variations in these requirements across the seasons, although the seasonal abundance of ectoparasites may vary widely between geographical regions (DURDEN et al., 2005).

The results obtained indicated that ectoparasite infestations are more frequent in male than in female dogs. This is in agreement with Chee et al. (2008), who reported that males had higher prevalence of ectoparasites. Furthermore, the majority of the infestations were recorded in large breeds and outdoor animals. These findings may be related to the characteristics of the population studied, which consisted predominately of males and guard dogs. Contact with other stray dogs, wild canids (The Iranian Department of the Environment has reported that foxes, jackals and wolves exist around Tehran and some protected areas of Tehran province) and/ or rodents can be considered important factors as well. Although the quantity of ectoparasites was higher among juvenile dogs, this difference was not statistically significant $(\mathrm{p}>0.05)$.

Pruritus, the major clinical sign, was more common in dogs infested with mites and fleas. A recent report showed that more than $29.7 \%$ of flea-infested dogs had pruritus (RINALDI et al., 2007). The variety of histamine-like compounds, enzymes, polypeptides and amino acids in the flea's saliva can induce type I, type IV and basophile hypersensitivity reactions (HALLIWELL et al., 1987), and therefore hypersensitivity reactions to flea saliva can be blamed for pruritus (GROSS; HALLIWELL, 1985; SCOTT et al., 2001). Feeding, burrowing and production of antigenic material by the mites can stimulate an inflammatory response (WALL;
SHEARER, 2001). Eosinophilia and low hematocrit levels were more frequently detected in cases of mite and tick infestations. Such blood alterations may have been caused by feeding behavior (blood-sucking) and antigen stimulation (WALL; SHEARER, 2001; SCHULTZE, 2010). However, there was no significant relationship between any of the ectoparasite infestations and the eosinophil count or hematocrit level. This is in accordance with Heukelbach et al. (2006) and Pilger et al. (2011) who reported that eosinophilia was not significantly associated with the presence of ectoparasites.

The present study provides new information about dog ectoparasite species, their seasonal occurrence, clinical signs and laboratory findings in Tehran, Iran. These results and the zoonotic importance of some of the ectoparasites warrant preventive and therapeutic programs to be used routinely all year round.

\section{Acknowledgements}

The authors declare that they have no conflicts of interest.

\section{References}

Agbolade OM, Soetan EO, Awesu A, Ojo JA, Somoye OJ, Raufu ST. Ectoparasites of domestic dogs in some Ijebu Communities, Southwest Nigeria. World Appl Sci J 2008; 3(6): 916-920.

Aldemir OS. Epidemiological study of ectoparasites in dogs from Erzurum region in Turkey. Revue Méd Vét 2007; 158(3): 148-151.

Bahrami AM, Delpisheh A. Common ectoparasite species of domestic dogs in western Iran. World Appl Sci J 2010; 8(10): 1277-1281.

Beck W, Boch K, Mackensen H, Wiegand B, Pfister K. Qualitative and quantitative observations on the flea population dynamics of dogs and cats in several areas of Germany. Vet Parasitol 2006; 137(1-2): 130-136. http://dx.doi.org/10.1016/j.vetpar.2005.12.021

Chee JH, Kwon JK, Cho HS, Cho KO, Lee YJ, El-Aty AMA, et al. A survey of ectoparasite infestations in stray dogs of Gwang-ju City, Republic of Korea. Korean J Parasitol 2008; 46(1): 23-27. http://dx.doi. org/10.3347/kjp.2008.46.1.23

Durden LA, Judy TN, Martin JE, Spedding LS. Fleas parasitizing domestic dogs in Georgia, USA: Species composition and seasonal abundance. Vet Parasitol 2005; 130(1-2): 157-162. http://dx.doi. org/10.1016/j.vetpar.2005.03.016

Edwards FB. Fleas. Vet Rec 1969; 85: 665

Faulde MK. Vector-borne Infectious Diseases in Iran. Washingto: DC publication; 2010. Available from: http://www.afpmb.org/sites/default/ files/pubs/dveps/Iran.pdf

Ghosh S, Bansal GC, Gupta SC, Ray D, Khan MQ, Irshad H, et al. Status of tick distribution in Bangladesh, India and Pakistan. Parasitol Res 2007; 101(S2): 207-216. http://dx.doi.org/10.1007/s00436-0070684-7

González A, Castro Dolores Del C, González S. Ectoparasitic species from Canis familiaris (Linné) in Buenos Aires province, Argentina. Vet Parasitol 2004; 120(1-2): 123-129. http://dx.doi.org/10.1016/j. vetpar.2003.12.001 
Gracia MJ, Calvete C, Estrada R, Castillo JÁ, Peribáńez MA, Lucientes J. Fleas parasitizing domestic dogs in Spain. Vet Parasitol 2008; 151(2-4): 312-319. http://dx.doi.org/10.1016/j. vetpar.2007.10.006

Gross TL, Halliwell REW. Lesions of Experimental Flea Bite Hypersensitivity in the Dog. Vet Pathol 1985; 22(1): 78-81.

Guzman RF. A survey of cats and dogs for fleas: with particular reference to their role as intermediate hosts of Dipylidium caninum. $N Z$ Vet J1984; 32(5): 71-73. http://dx.doi.org/10.1080/00480169.1984.35067

Halliwell RE, Preston JF, Nesbitt JG. Aspects of the immunopathogenesis of flea allergy dermatitis in dogs. Vet Immunol Immunopathol 1987; 17(1-4): 483-494. http://dx.doi.org/10.1016/01652427(87)90164-4

Harman DW, Halliwell RE, Greiner EC. Flea species from dogs and cats in north-central Florida. Vet Parasitol 1987; 23(1-2): 135-140. http:// dx.doi.org/10.1016/0304-4017(87)90031-8

Heukelbach J, Poggensee G, Winter B, Wilcke T, Kerr-Pontes LRS, Feldmeier H. Leukocytosis and blood eosinophilia in a polyparasitised population in north-eastern Brazil. Trans $R$ Soc Trop Med Hyg 2006; 100(1): 32-40. http://dx.doi.org/10.1016/j. trstmh.2005.06.021

Hewitt M, Walton GS, Waterhouse M. Pet animal infestations and human skin lesions. Br J Dermatol 1971; 85(3): 215-225. http://dx.doi. org/10.1111/j.1365-2133.1971.tb07219.x

Little SE. Vector-Borne diseases. In: Bowman DD. Georgis' parasitology for veterinarians. 9th ed. Missouri: Saunders Elsevier; 2009. p. 240-253.

Nithikathkul C, Polseela R, Iamsa-Ard J, Wongsawad C, Jittapalapong SA. A study of ectoparasites of Canis lupus familiaris in Mueang District, Khon Kaen, Thailand. Southeast Asian J Trop Med Public Health 2005; 36(S4): 149-151.
Nuchjangreed C, Somprasong W. Ectoparasite species found on domestic dogs from Pattaya District, Chon Buri Province, Thailand. Southeast Asian J Trop Med Public Health 2007; 38(S1): 203-207.

Pilger D, Heukelbach J, Diederichs A, Schlosser B, Araújo CPLC, Keysers A, et al. Anemia, leukocytosis and eosinophilia in a resourcepoor population with helmintho-ectoparasitic coinfection. J Infec Dev Ctries 2011; 5(4): 260-269.

Rinaldi L, Spera G, Musella V, Carbone S, Veneziano V, Iori A, et al. A survey of fleas on dogs in southern Italy. Vet Parasitol 2007; 148(3-4): 375-378.

Schultze AE. Interpretation of Canine Leukocyte Responses. In: Weiss DJ, Wardrop KJ. Schalm's veterinary hematology. 6th ed. Wiley-Blackwell; 2010. p. 321-334.

Scott DW, Miller WH, Griffin CE. Muller \& Kirk's small animal dermatology. 6th ed. Philadelphia: W.B. Saunders, Press; 2001.

Shoorijeh SJ, Ghasrodashti AR, Tamadon A, Moghaddar N, Behzadi MA. Seasonal frequency of ectoparasite infestation in dogs from Shiraz, Southern Iran. Turk J Vet Anim Scie 2008; 32(4): 309-313.

Tavassoli M, Ahmadi A, Imani A, Ahmadiara E, Javadi SH, Hadian M. Survey of flea infestation in dogs in different geographical regions of Iran. Korean J Parasitol 2010; 48(2): 145-149. http://dx.doi.org/10.3347/ kjp.2010.48.2.145

Wall R, Shaw SE, Penaliggon J. The prevalence of flea species on cats and dogs in Ireland. Med Vet Entomol 1997; 11(4): 404-406. http://dx.doi. org/10.1111/j.1365-2915.1997.tb00430.x

Wall R, Shearer D. Veterinary ectoparasites: biology, pathology and control. 2nd ed. Blackwell Sciences Ltd, Oxford, London. Press; 2001.

Xhaxhiu D, Kusi I, Rapti D, Visser M, Knaus M, Lindner T, et al. Ectoparasites of dogs and cats in Albania. Parasitol Res 2009; 105(6): 1577-1587. http://dx.doi.org/10.1007/s00436-0091591-x 